\title{
Perception of car workshop partners towards the vocational students' internship performance in Cilacap
}

\author{
Eka Rini Widiastuti*, Budi Santosa, Muhammad Sayuti \\ Master Program of Vocational Education Department, Universitas Ahmad Dahlan, Jl. \\ Pramuka, Yogyakarta, Indonesia \\ *Corresponding e-mail: riniwidiastutieka@gmail.com
}

\begin{abstract}
This research aims to determine the perceptions of industrial partners of the car workshop on the performance of vocational high school students in Cilacap after conducting internship program. The type of this research is descriptive qualitative. The data collection techniques used questionnaires. To test the validity and research data, we used triangulation of data that is how researchers test the validity of data by collecting similar data but by using different data collection techniques. The data to be concluded is about the performance of internship students. The performance of internship students is concluded with different methods, namely the questionnaire method and the interview method.
\end{abstract}

Keywords: industry, internship, perception, students' performance.

How to cite: Widiastuti, E. R., Santosa, B., \& Sayuti, M. (2021). Perception of car workshop partners towards the vocational students' internship performance in Cilacap. International Journal on Education Insight, 1(2), 61-68. DOI: http://dx.doi.org/10.12928/ijei.v1i2.2117.

\section{INTRODUCTION}

The development of automotive in this world has experienced very rapid progress marked by the number of luxury and sophisticated cars that are mushrooming in the market in Indonesia alone, as a developing country, there are several cars that have entered the market in 2019. In countries with populations most, the number of cars on the market reached 28.1 million, down 2.8 percent from the previous year (China), car sales in August 2019 in India fell to 115,957 units, from the same period the previous year 196,847, Germany 3.72 units, Indonesia 1.03 million units and the United States 17.33 million units This shows the high market demand against cars in various countries.

Table 1. Number of Vehicles in Various Countries

\begin{tabular}{lrrrr}
\hline Number of vehicles & \multicolumn{1}{c}{2014} & \multicolumn{1}{c}{2015} & \multicolumn{1}{c}{2016} & \multicolumn{1}{c}{2017} \\
\hline Passenger car & 12599038 & 13480973 & 14580666 & 15493068 \\
Bus car & 2398846 & 2420917 & 2486898 & 2509258 \\
Freight cars & 6235136 & 6611028 & 7063433 & 7523550 \\
Motorcycle & 92976240 & 98881267 & 105150082 & 113030793 \\
& & & & \\
Amount & 114209260 & 121394185 & 29281079 & 138556669 \\
\hline
\end{tabular}


Light Vehicle Engineering Skills Competency in general refers to the contents of Article 3 of the National Education System Law (SPN Law) concerning National Education Objectives and explanation of article 15 which states that vocational education is secondary education that prepares students especially to work in certain fields. there is a fact that training, and the utilization of skills learned in vocational education that are relevant to the world of work are indispensable for economic growth and national development. "Vocational education covers a very broad problem besides covering elements of education in general that are related to issues of leadership, planning, organizing, supervision, human resource management, performance, student, curriculum, counseling guidance, maintenance of infrastructure, finance, and integrated quality issues that are integrated applied in the context of education (Rahmayanti, Wibawa, \& Khaerudin, 2018). Specifically, the aim of the Light Vehicle Engineering Expertise Program is to equip students with the skills, knowledge and attitudes to have competent competencies. PKL is one of the implementation of link and match policy, is the policy of the Department of Indonesia that is developed to increase the relevance of vocational high schools (SMK) to the needs of the world of work, business and industry especially. The importance of implementing internship is because every SMK graduate must have good skills, competitiveness and work ethic.

According to Hamalik (2007), industry practice or in some schools called On The Job Training (OJT) is a training capital held in the field, aiming to provide the skills needed in certain jobs in accordance with the demands of ability for work. This is very useful for students to be able to adapt and be ready to go into the world of work, so that the work later can be in accordance with the demands of the world of work.). Internship are a place to shape students' mentality and character in accordance with the demands of the industry (Apandi, 2017). Vocational Schools are required to have partners, namely the business world and the industrial world ( $\mathrm{Du} / \mathrm{Di}$ ) or other appropriate institutions as a place to implement internship. (PKL) is a process of implementing systematic and scheduled learning materials that are carried out in industry. PKL is focused on exploring skills and mastery of expertise competencies by means of field practice.

Performance assessment is an assessment based on observers' observations of student activities as they occur. Performance when associated with performance as a noun (noun), then the notion of performance or performance is the work that can be achieved by a person or group of people in a company in accordance with their respective authorities and responsibilities in an effort to achieve company goals illegally, not violating legal and not contrary to morals and ethics (Zulmi, 2015). Assessments are performed on student performance, behavior, or interaction. Performance assessment is used to assess student abilities through assignments. The assignment is specifically designed to produce responses (oral or written), produce works (products), or demonstrate the application of knowledge. Assignments given to students must be in accordance with the competencies to be achieved and meaningful for students (Setyono, 2005). Besides being conducted by teachers, performance assessment is also carried out by workshop industry partners where vocational students carry out internship. The purpose of this article is to describe the perceptions of the car workshop industry partners on the performance of vocational high school vocational school students in Cilacap. 


\section{RESEARCH METHOD}

This type of research is descriptive qualitative. Descriptive qualitative research is a research method based on the philosophy of positivism, used to examine natural conditions of objects (Sugiyono, 2010). Descriptive method is a method in examining the status of a group of people, objects, conditions, systems of thought or events in the present. In this study, researchers describe and analyze the perceptions of car repair industry partners on the performance of student internship. The subjects of this study were DUDI. A total of 5 subjects were selected using convenient sampling techniques by considering the distance of the location of the partner and the school. Data collection techniques in this study used 2 ways, namely questionnaire and interview. Questionnaire is a tool used to collect data by making a list of questions in writing and then the respondent will be filled in a written manner as well. Interview is a data collection technique that is carried out in a structured or unstructured manner and can be done face-to-face or by using telephone networks.

The questionnaire and interview guidelines were prepared based on the partner's perception grid of the performance of internship students as presented in Table 2.

Table 2. Performance Grid of Students' Internship

\begin{tabular}{ll}
\hline \multicolumn{1}{c}{ Aspect } & \multicolumn{1}{c}{ Indicator } \\
\hline A. Learners Readiness & 1. Students have the ideal physical \\
& 2. Students have good health \\
& 3. Students have good mentality \\
4. Students have the skills according to \\
the procedure
\end{tabular}

\section{Questionnaire}

Data collection uses a questionnaire conducted by researchers to find out how much Student Street Student Performance. The questionnaire used by researchers is an open questionnaire because respondents are free to give statements in accordance with their wishes and interests from within themselves. In making the questionnaire statement in accordance with performance indicators. 
Table 3. Questionnaire

\begin{tabular}{|c|c|}
\hline NO & QUESTION \\
\hline 1 & PKL participants look polite \\
\hline 2 & $\begin{array}{l}\text { PKL participants said politely according to the applicable } \\
\text { procedures }\end{array}$ \\
\hline 3 & PKL participants attend on time \\
\hline 4 & PKL participants obey the rules that apply in DUDI \\
\hline 5 & PKL participants can communicate well with leaders and staff \\
\hline 6 & PKL participants can communicate well with consumers \\
\hline 7 & $\begin{array}{l}\text { PKL participants are able to use the equipment / facilities } \\
\text { available in DUDI }\end{array}$ \\
\hline 8 & $\begin{array}{l}\text { PKL participants are able to maintain work safety while at } \\
\text { DUDI }\end{array}$ \\
\hline 9 & PKL participants are able to know and and improve \\
\hline 10 & damage precisely \\
\hline 11 & PKL participants are able to provide speed in service \\
\hline 12 & $\begin{array}{l}\text { PKL participants are able to maintain the cleanliness and } \\
\text { tidiness of the workshop }\end{array}$ \\
\hline
\end{tabular}

\section{Interview}

The process of collecting data through interviews is done after students take part in internship. Respondents include students who take PKL learning. The purpose of the interview is to implement the material that has been obtained at school., Forming a mindset that builds apprenticeship students, Trains students to communicate and interact professionally in the real work world, Forms good work spirit for Prakerin students, Adds and develop basic knowledge possessed by students and internship students according to their respective fields, Add to the types of skills possessed by students so that they can be developed and implemented in everyday life, Establish good cooperation between schools and the industrial world or the business world. Data analysis The data analysis technique used in this study is data triangulation (methodological triangulation), which is a way for researchers to test the validity of data by collecting similar data but by using different data collection techniques. The data to be concluded is about the performance of Shiva PKL after learning PKL. The performance of PKL students is concluded with different methods, namely the questionnaire method and the interview method. After the data validity test is carried out, the following steps carry out the three steps of data analysis, namely data reduction, data presentation and conclusion drawing. Explanations related to the three data analyzes are as follows.

\section{Data Reduction}

Data reduction is carried out after all student response data on student performance after conducting internship is tested for validity. The process of reducing data in this study is to select incoming data about student internship' performance.

\section{Data Presentation}

Presentation of data in this study is to narrate student response data that has been reduced with a systematic narrative, structured so that it is easily 
understood by readers. The process of presenting this data so that what the researcher wants to convey can be well received by the readers.

\section{Drawing Conclusion}

Drawing conclusions in this study is to answer the problems raised in this study. This conclusion is expected to know how students' responses in general to the performance of internship students.

\section{RESULTS AND DISCUSSION}

Data from the results of this study are presented descriptively. The triangulation process is carried out until finally getting results. The triangulation technique used is the method triangulation, which compares the data between the results of cake and interviewer. This process is carried out so that students can carry out the maximum results of internship and DUDI can provide advice and infrastructure in accordance with what is desired by schools and researchers by giving several statements contained in a questionnaire based on DUDI assessment indicators The results obtained from filling out the questionnaire were classified and some of our respondents interviewed to increase the validity of the data obtained from the questionnaire data. The classification of results obtained from students after filling the questionnaire is as follows:

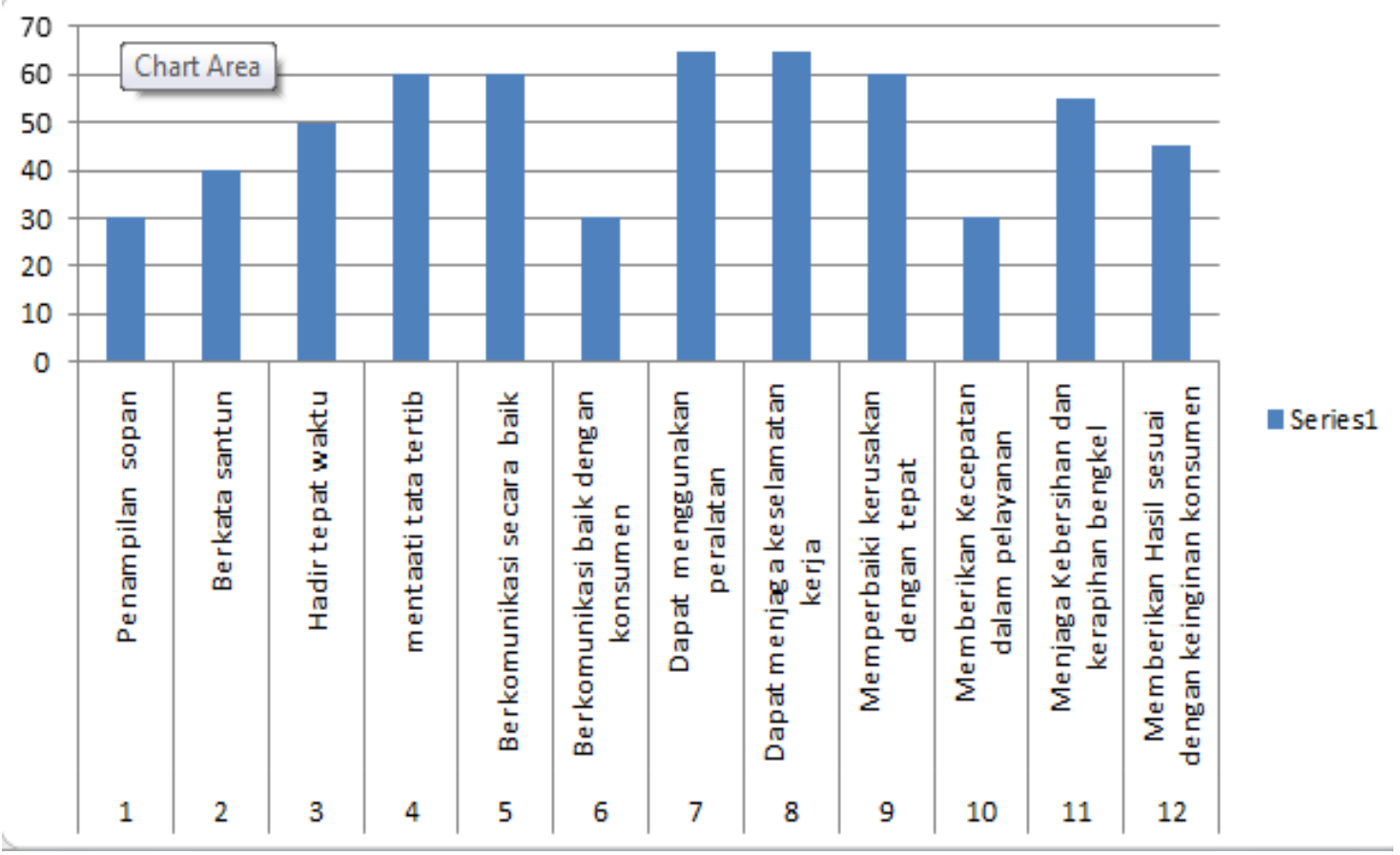

Figure 1. The classification of results obtained from students after filling the questionnaire

\section{Discipline of PKL Students}

The perception of the workshop industry partners on the discipline of students of 50 percent of industry practice and students present on time 60 percent of the workshop industry partners state that students obey the rules and regulations 55 percent of the workshop industry partners state that students are able to maintain the cleanliness and neatness of the workshop. In detail, 
the data obtained are as follows. a. PKL participants were present on time from the results of the questionnaire against DUDI on the aspect of material readiness, the partner gave a statement that courtesy when PKL covers $50 \% \mathrm{~b}$. PKL participants obey the rules that apply in DUDI from the results of the questionnaire to DUDI on the aspect of material readiness, the partner testifies that manners when the internship cover $60 \% \mathrm{c}$. PKL participants were able to maintain the cleanliness and tidiness of the workshop from the results of the questionnaire against DUDI on the aspect of material readiness, the partner gave a statement that manners when the internship covered $55 \%$ Based on the data above, it can be concluded that 55 percent of industrial partners have a good perception of the discipline of students in internship. This is in line with the results of the study which found that $85 \%$ of the workshop industry partners stated that the participation of industrial workers was included in the very good category (Hesti, 2015).

\section{PKL Student Performance}

The perception of the workshop industry partners on student performance, student competencies have an average of 53 percent. More details are described as follows. a. PKL participants are able to use the equipment / facilities available in DUDI from the results of the questionnaire against DUDI in the aspect of material readiness, partners provide information that manners when internship cover $65 \%$ b. PKL participants were able to maintain work safety while in DUDI from the results of the questionnaire against DUDI in the aspect of material readiness, partners gave information that manners when internship cover $65 \%$ c. PKL participants are able to find out and correct damage precisely from the results of the questionnaire on DUDI on the aspect of material readiness, the partner testifies that manners when the street vendor covers $60 \% \mathrm{~d}$. PKL participants are able to provide Speed in service from the results of the questionnaire to DUDI on the aspect of material readiness, partners provide information that manners when PKL covers 30\% e. PKL participants are able to provide results in accordance with the wishes of consumers from the results of the questionnaire to DUDI on the aspect of material readiness, partners provide information that manners when internship include $45 \%$ This is in line with the results of the study that found responsibility to get a score of 465 and the percentage of $74 \%$ included in the good category, cleanliness got a score of 290 and a percentage of $74 \%$ included in the good category, adaptation got a score of 496 and a percentage of $79 \%$ included in the good category, and attitude got a score of 492 and the percentage of $77 \%$ included in the good category (Dwi Mei Hesti 2015)

\section{Communication Skills of Internship Students}

The results of the research questionnaire data found an average communication ability of 43 percent which included: (1) PKL participants said that they were polite in accordance with the procedures in force from the results of the questionnaire towards DUDI on the aspect of material readiness, the partner gave a statement that manners when the internship covered 40\%; (2) PKL participants can communicate well with the leadership and staff of the results of the questionnaire to DUDI on the aspect of material readiness, partners provide information that manners when internship include $60 \%$; (3) PKL participants can communicate well with consumers from the results of the questionnaire to DUDI on the aspect of material readiness, partners provide information that manners when PKL covers 30\%. This is in line with the results

IJEI, Vol. 1, No. 2, October 2020, 61-68 
of research that found examining the relationship between students' perceptions of DU / DI communication in industrial work practices and entrepreneurial attitudes, Communication of 0.791 (Pradhana, 2012).

\section{CONCLUSION}

In connection with students 'perceptions of students' readiness is very less in the category of lack. Then the school increases the readiness of students by carrying out debriefing earlier and more mature so that students will be better prepared when plunging into the field. In connection with students' perceptions of student performance during the Industrial Work Practices category, students improve work skills so that DUDI feels satisfied and can benefit from having students implementing Industrial Work Practices. In connection with students' perceptions of the performance of DUDI instructors in the less category. Therefore, the instructor further improved his work ability in guiding and assisting vocational students during internship. In connection with students' perceptions of the benefits of Industrial Work Practices for students the category is lacking. So both the school and DUDI are more synergized again so that the apprenticeship can truly provide benefits both for students in creating a professional workforce and for DUDI to be able to absorb workforce as expected.

\section{REFERENCES}

Hesti, D. M. (2015). Persepsi Dunia Usaha Terhadap Unjuk Kerja Siswa SMK Negeri 1 KENDAL Jurusan Busana Butik pada Praktek Kerja Industri (Prakerin). Doctoral Dissertation. Semarang: Universitas Negeri Semarang. Kemdikbud. (2003). Undang-Undang Sistem Pendidikan Nasional. Jakarta: Kementerian Pendidikan dan Kebudayaan.

Pradana, K. G. (2012). Hubungan antara persepsi siswa tentang peran DUDI dalam praktik kerja industri dengan sikap kewirausahaan siswa kelas XII Teknik Permesinan SMK Negeri 6 Malang Tahun 2011.

Rahmayanti, A., Wibawa, B., \& Khaerudin, K. (2018). Peningkatkan Hasil Belajar Matematika dan Kemampuan Pemecahan Masalah Siswa SMA Melalui Pendekatan Saintifik. JTP-Jurnal Teknologi Pendidikan, 20(3), 181198.

Sidik, R. (2019). Analisis Layanan Industri Pada Tempat Prakerin Siswa Terhadap Penguasaan Kompetensi Teknik Kendaraan Ringan Siswa SMK N 5 Surakarta. Doctoral Dissertation. Surakarta: Universitas Sebelas Maret.

Sugiyono. (2010). Metode Penelitian Pendidikan Pendekatan Kuantitatif, Kualitatif dan $R \& D$. Bandung: Alfabeta.

Zulmi, A. E. (2015). Aplikasi Penilaian Kinerja Karyawan Menggunakan Metode Smart Berbasis Web Studi Kasus pada PT Prima Sarana Ekspress. Doctoral Dissertation. Universitas Darma Persada. 
